\title{
Otel İşletmelerinde Çalışanların Algıladıkları Örgütsel Destek Boyutları Üzerine Bir Model Önerisi*
}

\begin{abstract}
Hatice GÜÇLÜ NERGIZ**
Öz

Örgütsel destek teorisi, çalışan- örgüt ilişkilerini sosyal değişim teorisine dayanarak açıklayan ve anlamlandıran bir teoridir. Çalışanın örgütünden algıladığı desteğin büyük oranda yönetici ve çalışma arkadaşlarına bağlı olduğu görüşü yaygın olmakla birlikte, müşteri davranışları ve müşteri-çalışan etkileşiminin bu algılamayı etkileyip etkilemediği konaklama işletmeleri literatüründe yeterince incelenmemiştir. Bu çalışmada, entelektüel sermaye unsuru olarak müşterilerin çalışanların örgütsel destek algıları üzerinde etkide bulunup bulunmayacağı tartş̧ımaktadır. Bu bağlamda, turizm endüstrisinde insan kaynağı sermayesini ifade eden ve aynı zamanda entelektüel sermayenin bir unsuru olan müşteri sermayesinden hareket edilmiştir. Bu açıdan turizm endüstrisinde müşteri sermayesinin aynı zamanda çalışanların örgütsel destek algılamasını etkileyen bir boyut olarak ele alınabileceği iddia edilmektedir. Başka bir ifade ile bu çalışmada, entelektüel sermaye unsurlarından olan müşteri sermayesinin çalışanların algıladıkları örgütsel desteğin bir boyutunu oluşturduğu iddia edilmektedir. Çalışma, bu boyutla ilgili kavramsal ve görgül literatürün bir taraması niteliğindedir.
\end{abstract}

Anahtar Kelimeler: Örgütsel destek, entelektüel sermaye, müşteri sermayesi, müşteri-çalışan etkileşimi.

\section{A Proposed Model of the Dimensions of Perceived Organizational Support of Employees Working in Hotel Management}

\begin{abstract}
Perceived Organizational Support Theory is a theory based on explaining employee- organization relationship in terms of Social Exchange Theory. Although the common view is that a substantial part of an employee's perceived support of their organization come from their managers and fellow employees, there is an insufficient amount of research in hospitality management regarding whether customer behaviours and customer- employee interaction effect this perception. In this study, it is argued that whether customers as the components of intellectual capital will have an effect on an employee's perceived organizational support. In this context, the study has been conducted starting from customer capital which represents human capital source as well as the component of intellectual capital in tourism industry. From this perspective, it is claimed that customer capital in tourism industry may also contribute as a dimension to the perceived organizational support of the employees. In other words, in this study it is claimed that customer capital which is a component of the intellectual capital, forms a dimension of the employee's perceived organizational support. This study is based on the scanning of conceptual and empirical literature regarding this dimension.
\end{abstract}

Keywords: Organizational support, intellectual capital, customer capital, customeremployee interaction.

\footnotetext{
Çalışmanın hazırlanmasında, fikir veren Doç. Dr. Berrin GÜZEL'e; önerileri ile çalışmanın geliştirilmesinde katkılarda bulunan hakemlerimize teşekkürlerimi sunarım.

** Yrd. Doç. Dr., Çanakkale Onsekiz Mart Üniversitesi, Turizm Fakültesi Seyahat İşletmeciliği ve Turizm Rehberliği Bölümü
} 


\section{Giriş}

Turizm işletmelerinin emek yoğun ve sınırlı oranda teknoloji kullanabilme özelliklerinden dolayı yaşanan yoğun rekabette rakipleri karşısında ön plana geçebilmek için kullandıkları en önemli unsur, sahip oldukları beşeri kaynaklarıdır. Örgütlerin başarısı, çoğunlukla çalışanların sahip olduğu yeterliliklere bağlı olarak ortaya çıkmaktadır. Bu durum, tüm işletmelerde olduğu gibi turizm işletmelerinin de beşeri kaynaklarının değerini maddi kaynakların çok daha ötesine taşımaktadır. Beşeri kaynakların bilgi birikimi, tecrübe, yetenek ve öğrenmeye bağı oluşturduğu değer, konu ile ilgili bilim adamlarınca entelektüel sermaye olarak adlandırımaktadır. İnsan sermayesi, yapısal sermaye ve müşteri sermayesi olmak üzere üç ana unsurdan oluşan entelektüel sermaye, tarım, sanayi ve hizmet sektörlerinde faaliyet gösteren tüm işletmeler açısından önemli bir değer haline gelmektedir (Paksoy ve Öztürk, 2006: 134). Entelektüel Sermaye (ES) yaklaşımı ile ilgili ilk çalışmalar 1969 yılında John Kenneth Galbraith tarafindan incelenmiştir. Farklı bilim dallarında da incelenen bir konu olan entelektüel sermaye yaklaşımı yönetim bilimi literatüründe de ele alınmaktadır. Entelektüel sermayenin kaynağı bilgidir, bu bilginin işletme tarafindan kullanılması ve kullanılan bilginin işletme için bir değer yaratması ve bu değerin de maddi olmaması gerektiğinden hareket ederek (Emrem, 2004), entelektüel sermayeyi şöyle tanımlamak mümkündür: "Işletmeye değer katan, maddi olmayan tüm unsurlar"dır.

Müşteri ile ilişkiler, müşteri bağılığı, müşteri sadakati ve lisans anlaşmaları gibi unsurlar entelektüel sermayenin üçüncü unsuru olan müşteri sermayesini oluşturmaktadır. Müşteri sermayesi, işletmenin sahibi olmadığı bir varlık olup, işletmenin mevcut müşterileri ile ilişkilerini, müşterilerin işletmeye bağlııklarını ve işletme dışındaki kişilerle ilişkilerini kapsamaktadır (Kurgun ve Akdağ, 2013: 158). İşletme ile müşterileri arasındaki ilişkilerden dolayı sahip olduğu mevcut ve gelecekte elde edilmesi beklenen gelirler üzerinde önemli etkilere sahip bir sermaye türü olan müşteri sermayesi; müşteri ilişkilerinin değeri ve bu değerin işletmeye olan katkısı olarak ifade edilmektedir (Paksoy ve Öztürk, 2006: 141). Örgütsel destek teorisi, çalışanların duygusal intiyaçlarını karşılamak ve çalışanların yaptıkları katkılara organizasyonları tarafından ne kadar değer verildiği ve çalışanların iyiliğinin ne kadar düşünüldüğü ile ilgili olarak çalışanların genel bir inancını ifade eder (Orpen, 1994 alt. Börü ve Güneşer, 2006). Bu inanç, Eisenberger ve arkadaşları (1986) tarafindan Algılanan Örgütsel Destek olarak tanımlanmaktadır (Börü ve Güneşer, 2006).

Örgütsel destek; çalışanın örgütteki üyelerin (tarafların) kendisine değer vermesi ve mutluluğunu önemsemesine yönelik bir algılama tarzıdır (Kalağan, 2009). Bu algılamayı şekillendiren en önemli unsurun başında kuşkusuz yöneticiler ve çalışma arkadaşları gelmektedir. Bu çalışmada, turizm işletmeleri gibi hizmet sektöründe faaliyet gösteren ve çalışan-müşteri etkileşiminin yoğun olarak gerçekleştiği işletmelerde örgütsel destek algısının oluşmasında müşterilerin de önemli bir etkisinin olacağı varsayılmaktadır. Bu bağlamda, turizm işletmelerinde yönetici ve çalışma arkadaşı boyutlarının yanı sıra müşterilerin de örgütsel destek algılama sürecinde etkili olacağına dikkat çekmek gerekmektedir. Bu çerçevede hazırlanan bu çalışmada, ilgilialan yazın üzerinden sağlanan bilgilere dayalı olarak entelektüel sermaye boyutlarından müşteri sermayesine dayalı bir değerlendirme yapılarak, örgütsel destek algılamasında müşteri boyutunun önemi üzerinde durulacaktır. Çalışma, şimdiye kadar ortaya konan örgütsel destek algılama boyutlarına ek olarak müşteri boyutunu tartışması yönüyle önem taşımaktadır. Hizmet işletmelerinde müşteri- çalışan etkileşiminin önemi dikkate alındığında çalışmada sunulan modelin sadece otel işletmeleri kapsamında değil, diğer hizmet işletmelerinde de geçerli olabileceği ifade edilebilir. 


\section{KAVRAMSAL ÇERÇEVE}

\subsection{Entelektüel Sermaye Kavramı}

Bugünkü küresel çevre şartlarının niteliklerindeki hızlı değişim ve gelişmeler beşeri sermayenin önemine işletmelerin daha fazla dikkatini çekmiştir (Abeysekera, 2006). Küreselleşme, teknolojide değişimler, artan rekabet, müşteri talebindeki değişiklikler, ekonomik ve politik yapılardaki değişiklikler ile devletin bilgi ekonomilerini desteklemedeki artan rolü gibi çağdaş birtakım güçler işletmelerin iş yapma tarzlarını ve yollarını sürekli olarak yeniden şekillendirmektedir (Buckley ve Carter, 2000; Thorne ve Smith, 2000; Volberda vd. , 2001). Bu değişen şartlar işletmelerin beşeri sermayeye önem vermesini gerektirmiştir. Entelektüel sermaye, bu anlamda her örgütün sahip olduğu bir kaynak olup, bu sermayenin kavramsallaştrrılmasına ilişkin bir özet çalışma Tablo 1'de sunulmuştur (Bontis, 1998).

\section{Tablo 1. Entelektüel Sermayenin Kavramsallaştırılması}

\begin{tabular}{|c|c|c|c|}
\hline & & Entelektüel Sermaye & \\
\hline & İnsan Sermayesi & Yapısal Sermaye & Müşteri Sermayesi \\
\hline Özü & İnsani akıl & Örgütsel rutinler & Pazar ilişkileri \\
\hline Alanı & $\begin{array}{l}\text { İçsel müşteri olarak } \\
\text { çalışanlar }\end{array}$ & $\begin{array}{l}\text { İçsel örgütsel } \\
\text { bağlantilar }\end{array}$ & $\begin{array}{l}\text { Dışsal örgütsel } \\
\text { bağlantllar }\end{array}$ \\
\hline Parametreleri & Başarma hacmi & Etkinliğe ulaşılabilme & $\begin{array}{l}\text { Uzun ömürlülük } \\
\text { hacmi }\end{array}$ \\
\hline Zorluk düzeyi & Yüksek & Orta & En yüksek \\
\hline
\end{tabular}

Kaynak: Bontis, 1998, s. 66.

Edvindsson ve Malone (1997: 44) entelektüel sermayeyi, bir örgüte pazarda rekabet avantajı sağlayan bilgi, uygulanan tecrübe, örgütsel teknoloji, müşteri ilişkileri ve profesyonel yeteneklere sahip olmak olarak ifade etmiştir. Entelektüel sermaye unsurları ile ilgili olarak insan sermayesi, işletme çalışanlarının sahip oldukları bilgilerin, yeteneklerin ve deneyimlerin değeri olup, organizasyonel yenilik ve yenileme sürecinin temel kaynağını teşkil etmektedir (Ercan vd., 2003: 110).

Özellikle otel işletmelerinde insan sermayesinin önemli bir sermaye türü olduğu ifade edilebilir. Çalışanların eğitimi, nitelikleri, deneyimi, yabancı dil bilgisi ve ekip çalışmasına yatkınlığı gibi pek çok unsuru bu sermaye kapsamında değerlendirdiğimizde işletme başarısında ki üstlendiği rol ortaya çıkmaktadır.

Yapısal sermaye, entelektüel sermayenin ikinci unsuru olup; organizasyonun entelektüel sermayesinden faydalanmasını sağlayan yapıdır (Özdemir ve Balkan, 2010). Örgüt stratejisi, kültürü, misyonu, yönetim felsefesi, süreçler, bilgi teknolojisi/sistemleri, patentler, telif hakları, ticari marka, sırlar, amblemler, veritabanları, Ar-Ge, örgütsel şemalar, yenilik gibi tüm unsurlar yapısal sermaye içerisinde kabul edilmektedir (Guthrie, 2001; Tsan ve Chang, 2005). 
Bir örgütün insan sermayesindeki gizli olan niteliklerinin derecesini göstermek için bir örgütü çevreden somut bilgiler alan verimli bir süreç olarak düşünmek yararlı olabilir. Örgüt aynı zamanda çevreye somut ve yararlı bilgi çıkışları üreten kendi içinde bağlantı akışlarının olduğu içsel bir sistem olarak ifade edilebilir (Bontis, 1998). Günümüzde değişimin hızlı olması ve beklentilerin sürekli artması sebebi ile otel işletmelerinin başarısında kaliteli hizmet sunma önemli gerekliliklerden biri ve anahtar bir faktör olarak kabul edilmektedir. Başarının sağlanmasında hızlı değişimin olması ve müşterilerin artan beklentileri yöneticilere yön veren kılavuzların başında gelmektedir (Ma ve Qu, 2011). Bu özellikleri ile değerlendirildiğinde otel işletmelerinde entelektüel sermayenin önemi daha fazla ortaya çıkmaktadır. Hizmetin dokunulmaz oluşu (Lovelock, 1981), heterojen olması (Booms ve Bitner, 1981), üretim ve tüketimin ayrılmaz olması (Carmen ve Langeard, 1980) gibi hizmet sektörüne özgü özellikleri otel işletmeleri bağlamında değerlendirdiğimizde; hizmet genellikle müşterilere sınır birim çalışanları tarafindan yüz yüze bir ortamda sunulmaktadır. Müşterilerin hizmeti nasıl algılayacaklarını ise büyük ölçüde çalışanların müşterilerle etkileşimi belirlemektedir. Çalışanların kişilik, tutum ve becerilerinin benzersiz olması sebebi ile tüm müşterilere aynı şekilde hizmet sunumunu gerçekleştirmeleri oldukça zordur. Ayrıca, otel işletmelerinde müşterilerin ve çalışanların etkileşimi ile oluşan süreçte her iki tarafin fiziksel esenliği ve ruh durumu hizmetin sunumunu da etkileyen unsurlardır. Bu nedenle, çalışanların hizmet sunumundaki performans süreleri ve müşteri etkileşimleri farklılık gösterebilmektedir (Ma ve Qu, 2011). Bu durum ise hizmet işletmelerinde çalışanları etkileyen unsurlara müşterilerin de eklenmesini gerektirmektedir.

İnsanların hizmetin öneminin farkına varmaları, otel müşterilerinin memnun edilmesini de daha zor hale getirmiştir. Zeithaml'e (1987) göre müşterilerin hizmet kalitesini algılamaları, bekledikleri ile aldıkları hizmeti karşılaştırmaları sonucunda oluşmaktadır. Müşterilerin beklentilerini karşılayan hizmet sunulduğunda müşteri tatmin olur. Memnun edici bir hizmet deneyimi müşterinin de beklentilerini artıracağından bir sonraki hizmet deneyiminin de karşılanmasını daha zor hale getirecektir. Rekabet arttıkça, otel işletmeleri de hizmet kalitesinin önemini dikkate almaya başlamıştır. Bugünün müşterileri daha fazla seçeneğe ve her zamankinden daha fazla tercih kriterine sahiptir (Ma ve Qu, 2011). Bu nedenle, otel işletmelerinin çalışanlarının her türlü davranış ve tutumunu etkileyen unsurları dikkate almaları ve bu doğrultuda hareket etmeleri gerekmektedir.

\subsection{Algılanan Örgütsel Destek Teorisi}

Müşteri memnuniyetini sağlamada bu kadar önemli rolü olan çalışanların, sundukları hizmetten müşterilerin memnun olmasını sağlayan ana unsurlardan biri haline gelmesi, sosyal güç elde etme açısından çalışan ile örgüt arasındaki ilişkinin öneminin de artmasına sebep olmuştur (Güzel ve İşçi, 2015). Bu ise çalışanların örgütsel destek algılarının oluşumunu etkilemiş ve bunun önemini ortaya koymuştur. Çalışanların bu algılarının oluşmasında, örgütün çalışanlarının menfaatine önem vermesi esastır.

Algılanan örgütsel destek, çalışanların yararına olacak faaliyetleri ve uygulamaları çaııştkları örgütün gönüllü olarak gerçekleştirdiğine yönelik algılarıdır (Eisenberger vd., 1986: 500). Başka bir tanıma göre algılanan örgütsel destek, örgüt çalışanlarının, arkalarında örgütün varlığını bilerek kendilerini güvende hissetmeleri olarak ifade edilmektedir (Özdevecioğlu, 2003: 116). Tanımlar incelendiğinde; bir çalışanın bulunduğu örgütte sunduğu iş ve/veya hizmet karşılığında örgütünün çalışanı ne derece desteklediğine yönelik algılaması vurgulanmaktadır. 
Algılanan örgütsel destek kuramı, Blau'nun (1964) sosyal değişim teorisine dayalı olarak incelenmektedir. Buna göre, çalışanların işleri için sergileyeceği çaba ve performans düzeylerinin, örgütün kendilerine geleceğe yönelik vaat ettiği maddi ve manevi ödüllere bağlı olduğu belirtilmektedir. Örgütsel destek algısı zamanla, iş̧̧i ve işveren arasındaki etkileşime bağı olarak gelişim göstererek; örgütün kendilerine ne düzeyde bağlı olduğuna yönelik çalışanların algılarını yansıtmaktadır (Stamper ve Johlke, 2003: 571-572). Örgüt tarafindan kendilerine değer verildiğini ve önemsendiğini algılayan çalışanların, kendisinden istenen tutum ve davranışları yerine getirdiğinde, bunun örgüt tarafindan farkına varılacağı ve kendilerinin ödüllendirileceği konusunda örgüte karşı güven duyguları da artabilmektedir (Wayne vd., 1997: 83). Böyle bir durumda çalışanlar, başarılarının karşılığını göreceği konusunda güven duyduklarından, örgüt için çaba harcamaya ve ekstra performans göstermeye daha hevesli olabilmektedir. Rhoades ve Eisenberger'in (2002: 698), algılanan örgütsel destek konusuyla ilgili 70'den fazla çalışmayı inceleyerek yaptıkları meta-analiz çalışmasında, çalışanların örgütsel destek algısının; iş tatmini, olumlu ruh hali, duygusal bağlıık, iş performansı ve örgütte kalma niyeti ile pozitif ilişkili olduğu tespit edilmiştir.

Algılanan örgütsel destek kuramının temelinde, çalışanların örgüte insani özellikler yükleyerek, örgüt hakkında değerlendirme yapması bulunmaktadır (Aselage ve Eisenberger, 2003: 492). Yani çalışanlar örgütü bir bütün olarak ve insani özelliklere sahipmiş gibi değerlendirerek, kendilerine örgüt tarafindan fayda sağlanmasını bekleyebilmektedir. Yüksek örgütsel destek algısının, çalışanların; beğenilme, saygı duyulma, sosyal kimlik, duygusal destek gibi intiyaçlarının karşılanabilmesine imkân sağlayabileceği belirtilmektedir. Yine örgütsel destek algısı yüksek olan çalışanların, örgütsel bağılıklarının, iş performanslarının ve rol fazlası davranışlarının da artacağı, tersi durumda ise azalacağı ifade edilmektedir (Eisenberger vd., 1997: 812-813).

Yapılan açıklamalardan sonra örgütsel destek algıSı, çalışanların, örgüt tarafindan kendilerinin refahlarının dikkate alındığına ve örgüt için yaptıkları katkılara değer verildiğine yönelik inançları olarak ifade edilebilir. Çalışanların örgütü bir bütün olarak ve insani özelliklere sahip olarak görmesi sebebiyle, örgüt hakkındaki olumlu veya olumsuz düşüncelerini de direkt olarak örgütün bütününe atfedebilmektedir. Örneğin, bir örgüt çalışanının, örgüt dışındaki bir yakınına, bu işletmede çalışana değer verilmiyor, maaşlar çok düşük gibi eleştiriler yapması direkt olarak örgüte karşı söylenen düşünceler olmaktadır. Belki de bu durumun böyle olmasına neden olan işletme yöneticileri olabilir. Bu sebepten işletme yöneticilerinin de bir anlamda örgütün bütününün bir temsilcisi olduğu söylenebilir.

Rhoades ve Eisenberger (2002: 699); bu teori kapsamında algılanan örgütsel desteğin altında yatan psikolojik süreçleri şu şekilde açıklamıştır;

- Illk olarak, algılanan örgütsel desteğin karşııılılık normuna dayalı olması gerektiği belirtilmektedir. Algılanan örgütsel desteğin örgütün refahını dikkate alması ve hedeflerine ulaşmada katkı sağlaması gerekmektedir,

- İkinci olarak, algılanan örgütsel desteğin, çalışanların örgütteki üyeliklerine ve statülerine göre sosyo-duygusal ihtiyaçlarını (onaylanma, saygı, önemsenme gibi) karşılaması gerekmektedir,

- Üçüncü olarak ise, algılanan örgütsel desteğin, örgütteki ödüllendirme sisteminin performans odaklı işlediği konusunda çalışanların inançlarını arttırması gerekmektedir, 
- Son olarak da, tüm bu faaliyetlerin hem çalışan (iş tatmini, pozitif ruh hali vb.), hem de örgüt açısından (duygusal bağıııı, iş performansındaki artş̧, işgücü devir orandaki düşüş vb.) olumlu sonuçlar doğurması gerekmektedir.

Örgüt tarafından gerçekleştirilen; ödüllendirme, çalışma şartlarının iyileştirilmesi, ekstra ücret, terfi olanağı, iş zenginleştirme gibi katkıların çalışan üzerinde örgütsel destek algısı yaratabilmesi için, bu katkıların örgüt tarafından gönüllü olarak yapıldığına çalışanların inanmaları gerekmektedir. Çünkü bazı katkılar gerek devlet tarafından uygulamaya konulan yasalar nedeniyle (sağlık ve güvenlik koşullarının iyileştirilmesi vb.), gerekse sendikalarla yapılan anlaşmalar nedeniyle mecburi olarak yapılması gerekmektedir. Bu şekilde yapılan katkıların çalışan üzerinde örgütsel destek algısı yaratmayacağı belirtilmektedir (Rhoades ve Eisenberger, 2002: 698; Eisenberger vd., 1986: 501; Eisenberger vd., 1997: 813; Shore ve Shore, 1995: 150).

\section{KAVRAMSAL MODELIN GELIŞiMi}

Otel işletmeleri kapsamında değerlendirildiğinde, müşterilerle yoğun etkileşimde bulunan çalışanların yöneticileri, çalışma arkadaşları ve müşterilerden oluşan üç grup ile arasında sosyal değişim olmaktadır. Sırasıyla bu değişimler, (1) lider-üye değişimi, (2) çalışma arkadaşı değişimi ve (3) müşteri-çalışan değişimi olarak adlandırılmaktadır (Şekil 1).

AÖD-YD: Algılanan Örgütsel Destek- Yönetici Desteği, AÖD-ÇAD: Algılanan Örgütsel Destek Çalışma Arkadaşı Desteği, $A O ̈ D-M D:$ Algılanan Örgütsel Destek- Müşteri Desteği

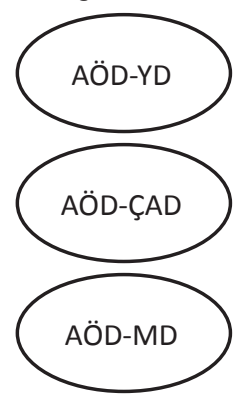

Şekil 1. Üç Boyutlu Algılanan Örgütsel Destek Çerçevesi

Lider-üye değişimi ve çalışma arkadaşı değişimi yönetim literatüründe daha fazla ilgi çeken konular iken, müşteri-çalışan değişimi çok fazla ilgi çeken bir konu olmamıştir (Organ vd, 2006). Ancak, müşteri- çalışan değişimi otel işletmelerinde iki sebepten dolayı önem taşımaktadır: Birincisi, otel çalışanları bağımsız çalışan kişiler değillerdir.

Aksine, yüksek kaliteli hizmetin sunulabilmesinde temel koşullardan biri otel çalışanlarının büyük ölçüde ekip çalışması sergilemesine bağlıdır. İkinci olarak, müşterilere hizmet sunmak otel çalışanları tarafindan en önemli görev olarak kabul edilir. Ayrıca, otel işletmelerinde müşteriler hizmetin pasif birer alıcısı konumunda olmayıp, hizmete aktif olarak katılmaktadırlar (Sierra ve Mc Quitty, 2005). Örgüte katkıda bulunma yönünde gönüllü sergilenen tüm davranışları ifade eden örgütsel vatandaşlık davranışının boyutları ile ilgili olarak Borman ve Motowidlo (1993) hizmet odaklı işletmelerin kendilerine has özelliklerinden dolayı bu işletmelerde çalışma arkadaşları ve yöneticiler boyutları dışında farklı bir boyutunda yer alması gerektiğini belirtmiştir. 
Araştırmacılar, müşteri boyutunun hizmet işletmelerinde örgütsel vatandaşlık boyutlarından biri olduğunu ileri sürmüştür (Ma ve $Q u, 2011$ ). Benzer bir yaklaşımın örgütsel destek algılamasında da yürütülebileceğinden hareketle otel işletmelerinde müşterilerin örgütsel destek algılamasını etkileyen bir boyut olabileceği iddia edilmektedir. Bu nedenle hizmet deneyiminin başarısı büyük oranda müşterilerin katılımına bağııdır. Müşteriler ve çalışanlar arasındaki etkileşimi dikkate alarak, bu çalışmada sosyal değişim teorisinin kapsamı genişletilerek lider-üye değişimi, çalışma arkadaşları değişimi ve müşteri- çalışan değişimi örgütsel destek algılamasının bir boyutu olarak ele alınmaktadır (Ma ve Qu, 2011).

Hizmetler kendiliğinden interaktif bir ortamda gerçekleşir ve müşterilerin hizmet deneyiminden tatmin olup olmamasında müşteriler ile çalışanlar arasındaki etkileşimin kalitesi çok önemlidir. Bu nedenle, hizmet sektöründe çalışanların müşteri odaklı olmaları müşterilerin hizmetten memnun olmasında kilit bir rol oynamaktadır (Lee vd. , 2011).

Tüm bu konular dikkate alındığında, çalışanların örgütsel destek algılamalarında sadece yöneticiler ve çalışma arkadaşlarının etkili olmayıp, müşterilerin otel işletmeleri için önemli bir beşeri sermaye unsuru olmalarından dolayı, müşteri- çalışan değişiminin de örgütsel destek algılamasında bir boyut olarak etkide bulunduğu iddia edilmektedir. Bu amaçla, ilk olarak müşteri sermayesi kavramının tanımlanması, otel işletmelerinde çalışanların örgütsel destek algılamalarını etkileyen bir unsur olarak müşteri sermayesinin hangi alt boyutlardan oluşacağı mevcut literatür üzerinden ortaya konulmaya çalışılacaktır.

Müşteri sermayesi, bir organizasyonun iş ilişkileri yoluyla geliştirdiği piyasa kanallarında ve müşteri ilişkilerinde gömülmüş olan bilgidir (Bontis, vd., 2000: 88). Müşteri sermayesi, bu bilgilere dayalı ilişkilerdir ve bu ilişkiler müşteriler, tedarikçiler, paydaşlar, stratejik işbirlikleri ile örgütsel ilişkilerde gömülü bilgilerden oluşmaktadır (Pablos, 2002: 289).

Sveiby (1997), işletmenin görünmeyen varlıklarının bir göstergesi olarak müşteri sermayesini sunan öncülerdendir ve müşteri sermayesini "dışsal sermaye" olarak ele almıştrr. Edvinsson ve Malone (1997) ise, müşteri sermayesini değerlemek için müşteri türü, müşteri devamlılığı, müşteri rolü, müşteri desteği ve müşteri başarısı gibi beş temel ölçüm geliştirmiştir. Entelektüel sermayenin önemli bir bileşeni olan müşteri sermayesi, bilgi ekonomisinde rekabet avantajının temel bir kaynağı olarak düşünülmektedir. Müşteri sermayesi, örgütün müşterilerle ilişkileri sonucunda ortaya çıkan ve mevcut ve gelecekteki gelirlere katkı sağlayan değerdir.

Bu nedenle müşterilerle uzun dönemli kazançlı bir ilişki kurmak günümüzde akıllı organizasyonların çalışmalarının odak noktası olmuştur (Chang ve Tseng, 2005: 253). Müşteri sermayesi, müşteri memnuniyeti, müşteri sadakati, imaj, marka ve doğrudan dağıtım kanallarını, markalar, müşteriler, müşteri bağlılığı, dağıtım kanalları, işe ilişkin işbirlikleri, lisans anlaşmaları, istenen nitelikteki anlaşmalar ve imtiyaz (franchising) anlaşmaları yer almaktadır (Guthrie, 2001: 35; Rudez ve Mihalic, 2007: 190). Müşteri sermayesine ilişkin farklı yazarlar tarafindan yapılan sınıflamalar ve açıklamalarına ilişkin bilgiler Tablo 2'de verilmiştir (Castro vd., 2004: 577). 
Tablo 2. Müşteri Sermayesine ilişkin Faktörler

\begin{tabular}{|c|c|c|}
\hline Yazar & Sınıflaması & Açıklama \\
\hline $\begin{array}{l}\text { Kaplan ve Norton } \\
\text { (1992) }\end{array}$ & Müşteri bakış açısı & $\begin{array}{l}\text { Müşteri ilişkileri, ürün ve hizmetlerin nitelikleri, } \\
\text { pazar payı, müşteri bağlılığı ve memnuniyeti, imaj } \\
\text { ve ün }\end{array}$ \\
\hline $\begin{array}{l}\text { Edvinsson ve } \\
\text { Malone (1997) }\end{array}$ & Müşteri portföyü & $\begin{array}{l}\text { Müşteri sermayesi; müşteri rolü, müşteri desteği, } \\
\text { müşterilerle elde edilen başarılar, müşterilerle } \\
\text { çalışma süresi }\end{array}$ \\
\hline Brooking (1996) & Pazar varlıkları & $\begin{array}{l}\text { Marka, müşteri bağlılığı, dağıtım ağları, örgüt } \\
\text { imajı süresi, dağıtım, örgüt işbirliği anlaşmaları, } \\
\text { müşteri portföyü }\end{array}$ \\
\hline Sveiby (1997) & Dış yapı & $\begin{array}{l}\text { Müşteri sınıflandırması, müşteri tabanlı büyüme, } \\
\text { müşteri verimliliği, müşteri istikrarı }\end{array}$ \\
\hline
\end{tabular}

Kaynak: Castro, vd., 2004: 577.

Ma ve Qu (2011), çalışmasında sosyal değişim teorisinin, çalışanlar ve müşteriler arasındaki etkileşimin örgütsel vatandaşlık davranışını motive ettiğini ortaya koymuşlardır. Otelcilik sektörü, liderler ve üyeleri (lider-üye değişimi) ile çalışma arkadaşları (çalışma arkadaşı değişimi) arasında etkileşimlerin oldukça fazla olduğu işletmelerden biridir. Ayrıca, otel işletmeleri "Insan Endüstrisi" olarak ifade edilen ve çalışanların müşterileri ile sürekli etkileşimleri aracılığıyla hizmet sundukları bir alandır. Illişkisel pazarlama literatüründe çalışanlar ile müşteriler arasındaki etkileşimin uzun vadeli ilişkilerin inşasında önemli bir kanal olduğu görüşü kabul görmeye başlamıştır. Bu sebeple, otel işletmelerinde yüksek kaliteli hizmetin yaratılmasında sosyal değişim sürecindeki müşteri- çalışan etkileşimi son derece önemlidir (Şekil 2). Pozitif örgütsel davranış, pozitif psikolojide gelişmeye başlayan ve araştırmacıların ilgisini çeken bir konu olmaya devam etmektedir (Wu vd,, 2014). Bu kapsamda ele alınan çalışanların örgütsel destek algılarının örgütsel ve bireysel açıdan önemli sonuçlarının olduğu yapılan araştırmalarla da (Arshadi ve Hayavi, 2013; Chen vd., 2005; Ferris vd., 2009; Fuller vd., 2003; Shore ve Wayne, 1993; Wayne vd., 1997; İplik vd., 2014; Edmondson ve Boyer, 2013; Arshadi, 2011; Bishop vd., 2000) ortaya konmuştur. Algılanan örgütsel desteğe yönelik araştırmalar, kavramın öncül ve sonuç değişkenlerini ortaya koymanın yanı sıra aracılık yaptığı ilişkileri de belirlemeyi amaç edinmiştir. Ancak yapılan literatür incelemesinde, algılanan örgütsel destek ve ilgili diğer örgütsel değişkenlerden hangilerinin öncül, hangilerinin sonuç, hangilerinin de aracı değişkenler olduğuna ilişkin tam bir görüş birliğine varılamadığı saptanmıştır (Giray, 2013).

Şekil 2. Otel İşletmeleri Bağlamında Sosyal Değişim Teorisinin Boyutları

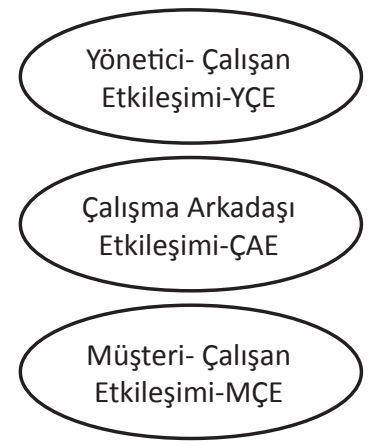


Otel çalışanları, uluslararası rekabetinde artması sonucunda daha fazla prososyal davranışlar sergilemek durumundadırlar. Çalışanların prososyal davranışlar sergilemeleri (örgüt yararını gözetme, örgütün amaçlarına ulaşmasını sağlamada faydalı olacak davranışlar gösterme) otel işletmelerinde bir zorunluluk olarak karşımıza çıkmaktadır (Fuller vd., 2006: 328-331). Bunun en büyük sebebi bu işletmelerin, farklı kültürlerden müşterilere hizmet sunmaları, müşterilerin demografik ve sosyo-kültürel özelliklerinin hızlı bir biçimde değişmesi; otel işletmelerini farklılık yaratmaya zorlamaktadır. Bu farklılaşmayı müşterilerine sunmayı hedefleyen işletmelerin olumlu müşteri deneyimi yaratabilmesi için çalışanların işletmenin değer ve beklentilerini kendi değer ve beklentileri gibi anlayıp kavraması gerekmektedir.

\section{GELIŞTIRILEN MODELE ILIŞKIN LITERATÜR BULGULARI}

Özdaşı ve arkadaşları (2013), yöneticileri ile daha fazla informal ilişkiler geliştiren, onlardan ekstra destek alan çalışanların, yani yöneticilerin "iç grup" diye tanımladıkları çalışanların ilk olarak örgütlerine yönelik, daha sonrada arkadaşlarına ve kendilerine yönelik proaktif davranışlar geliştirdikleri bulgusuna ulaşmıştır. Masterson (2001) örgütsel destek teorisi ile tutarlı olarak ele aldıkları sosyal değişim teorisi analizinde, çalışanların örgütten aldıkları olumlu (lehlerine olan) davranışların karşıı̆ı̆ını geri ödemeyi bir yükümlülük olarak algıladıklarının önemini vurgulamışlardır. Araştırmacılar; hizmet çalışanlarının, müşterilere yönelik duygu, düşünce ve tutumlarının çalışanların örgütsel destek algılamasına katkıda bulunduğunu ifade etmiştir. Benzer şekilde, Bell ve Menguc (2002), yüksek örgütsel destek algılamasına sahip servis çalışanlarının müşterilere karşı düşük örgütsel destek algılaması olan çalışanlara göre daha dikkatli, nazik olduklarını, müşterileri tarafindan değerlendirildiğini saptamıştır. Yapılan uygulamalı (ampirik) araştırmalarda (Rhoades ve Eisenberger, 2002), çalışanlarda olumlu davranışlar, beklenenden daha fazla çaba harcayarak örgütsel amaçlara ulaşma çabası, duygusal bağlılık, olumlu ruh hali, iş tatmini, iş sorumluluklarını yerine getirmede dürüstlük ve örgüt adına yeniliklerde bulunma gibi pek çok değişkenin algılanan örgütsel destek artışıyla ilgili olduğu tespit edilmiştir. Örgütsel desteğin oluşumu, psikolojik bir süreç olarak işlemekte ise de, bu algılama aynı zamanda sosyal bir süreçtir (Zagenczyk vd., 2010). Hizmet kalitesinin niteliği, örgütün müşteri odaklı çalışma ve uygulamalarına bağı olarak ortaya çıkmaktadır. Örneğin, çalışanların müşterilere üstün bir hizmeti sunma arzusunun olması gibi.

Servis çalışanları ve müşteriler arasındaki etkileşim hizmetin üretimi esnasında oluşur. Çaıışanların hizmet sunumu esnasındaki tutum ve davranışları, müşterilerin hizmet kalitesini algılamalarını da etkiler (Hartline ve Ferrell, 1996). Çalışanların hizmet sunumu sırasında müşterilerle arasındaki etkileşimdeki sıcaklık ve samimiyet müşteri bağlılığı oluşturmak için de önemli bir araçtır. Örgütün hizmet kalitesine bağ|ı̆ı̆ı, kurumun müşteri odaklılı̆̆ına da yansıyacaktır (Chow vd., 2006). Bunu başarmanın temelinde ise örgütün çalışanlarına değer vermesi ve çalışanların sosyal ihtiyaçlarını da gözetmeleri gerekmektedir. Hogan ve arkadaşları (1984), müşteri odaklılığı, müşterilere düşünceli, yardımsever ve işbirliği içinde hizmet etme eğilimi olarak tanımlamıştı. Örgütte faaliyetler, çalışanların tutum ve davranışlarının müşteri ihtiyaçlarını tatmin etmeye yönelik olmalıdır. Müşterilerle ilişkilerin kurulmasında sadakatin oluşumu ve hizmetin sunum sürecinin iyileştirilmesi için yeni fikirler edinmek çok önemlidir. Çalışanlar, hizmet işletmelerinde müşterilerin işletme ile ilgili deneyimlerinin önemli bir parçasıdır (Chow vd., 2006). Çalışanların örgütsel destek algılamalarının yüksek olması, müşterilere de daha iyi hizmet sunmalarını sağlar. Çalışanlar, yöneticilerine ve çalışma arkadaşlarına işle ilgili görevlerini yerine getirirken onlara yardımcı olmak için istekli olur ve bunu başarabileceklerinin mümkün olduğuna inanırlar. 
Servis çalışanları, hizmet işletmesinin müşterilerle en önemli arayüzü konumundadırlar. Bu sebeple, bu işletmelerde çalışanın göstereceği her davranış ve tutum müşterinin hizmet memnuniyetini oluşturmadaki kilit rol oynamaktadır (Riley, 1996; Wood, 1997).

Örgütsel vatandaşlık davranışının müşteri odaklı yönü ile ilgili yeni bir sınıflandırma önerisinde bulunulmuştur. Buna göre müşteri odaklı örgütsel vatandaşlık davranışı; müşteri memnuniyetini ve hizmet sunumunu geliştirmek için çaba harcaması gerekmeyen, ancak müşteri memnuniyeti ve hizmetin sunulmasında gönüllü olarak ek çaba harcayan çalışanların davranışlarını ifade eder (Dimitriades ve Maroudas, 2007). Müşterilerin ihtiyaçlarını ve sorunlarını tahmin etme, hizmetin etkinliğini sağlamayı kişiselleştirebilme ve müşterilerin kendilerini özel hissedebilmesini sağlayacak davranışlar bu kapsamda ele alınabilir (Lyu vd., 2016).

Örgütsel vatandaşlık davranışlarının boyutları içerisine katılan bu yeni sınıflama; özellikle çalışanların müşterilerle doğrudan etkileşimlerinin olması ve dışarıdan insanlara karşı örgütün çalışanlar tarafından temsil edilmesi gereken işletmelerde bu konu araştırmacılar tarafından da ilgi çekmiştir (örneğin, Bettencourt vd., 2001; Borman ve Motowidlo, 1993; Podsakoff ve MacKenzie, 1997). Gerçekten müşteri odaklı örgütsel vatandaşlık davranışı otel işletmeleriyle son derece ilişkili (Dimitriades ve Maroudas, 2007; Wu vd., 2014) olup, otel işletmelerinde müşteri hizmet kalitesini, müşteri memnuniyetini ve misafirperverliğin etkin işleyişini iyileştirmede büyük bir rol oynamaktadır (Hennig-Thurau, 2004; Podsakoff ve MacKenzie, 1997).

\section{SONUÇ}

Bu çalışmada, otel işletmelerinde algılanan örgütsel destek kavramının tanımı, kapsamı ile boyutları otel işletmelerine özgü özelliklerden ve entelektüel sermaye boyutlarından müşteri sermayesine dayanarak değerlendirilmiştir. Algılanan örgütsel destek, çalışanların örgüt tarafından refahlarının önemsendiğine ve örgüt için sağladıkları katkılara değer verildiğine yönelik algılamalarını ifade etmektedir. Sosyal değişim kuramına dayalı olarak açıklanan örgütsel destek algısının çalışan- yönetici etkileşimi ve çalışma arkadaşları ile olan etkileşimlerinin sonucunda oluştuğu yapılan çalışmalarla ortaya konmuştur.

Sosyal değişim kuramı doğrultusunda algılanan örgütsel desteğin boyutları ele alındığında çalışanların bu algılamalarını belirleyen önemli boyutlardan birisinin de çalışanmüşteri etkileşimlerinin olduğu iddia edilmektedir. Otel işletmelerinde çalışanlarla müşteriler arasındaki yoğun etkileşim, müşterilere hizmet sunumunun gerçekleştiği ortamın aynı zamanda çalışanların iş ortamını oluşturması gibi pek çok durum göz önüne alındığında örgütsel destek algılamasında müşteri-çalışan etkileşiminin de üçüncü bir boyut olarak ele alınması gerektiği ifade edilebilir. Bu iddianın ileri sürülmesindeki temel dayanaklardan biri de, çalışanların gönüllü olarak katkı verme yönünde sergilediği davranışları ifade eden örgütsel vatandaşlık davranışının bir boyutu olarak da ileri sürülen müşteri boyutunun (Güçlü Nergiz, 2016; Dimitriades ve Maroudas, 2007) benzer şekilde algılanan örgütsel desteğin boyutlandırılmasında da kullanılabileceği varsayımına dayanmaktadır. İşletmeye değer katan ve maddi olmayan unsurları ifade eden entelektüel sermaye unsuru olan müşterilerin çalışanların örgütsel destek algılamalarını da belirlemede etkili olduğu ileri sürülmüştür. Çalışan ile örgüt arasındaki iletişimin niteliği, örgüt değerlerinin çalışanlara katkı sağlaması ve çalışanların refahını önemsemesi örgütsel destek algılamasını etkilemektedir. Bu algının oluşumunda otel işletmelerinde yönetici ve çalışma arkadaşı etkileşiminin yanı sıra, müşteri- çalışan etkileşiminin örgütsel destek algılamasının bir boyutu olduğu düşünülmektedir. 
Çalışanlar örgütü oluşturan temel unsurları, davranışlarını değerlendirerek, bu davranışın altında yatan motivasyonları algılarlar (Demircan Çakar ve Yıldız, 2009: 76). Örgütsel destek algılaması ise yöneticiler, çalışma arkadaşları ve müşterilerin bir bütün olarak çalışana yönelik davranışlarının değerlendirilmesiyle oluşur. Örgütsel destek algısının bireysel ve örgütsel yaratacağı olumlu sonuçlardan otel işletmelerinin faydalanması sağlanabilir.

Literatürde de algılanan örgütsel destek ile örgütsel bağlıık boyutları (Özdevecioğlu, 2003; Gakoviç ve Tetrick, 2003), iş tatmini (Yoon ve Thye, 2002), örgütsel özdeşleşme (Sluss vd., 2008) ile arasında olumlu ilişkiler olduğu saptanmıştır. Buradan hareket ederek, otel işletmelerinde çalışanların örgütsel destek algılamasında müşteri sermayesinin de üzerinde önemle durulması gerekliliğini ortaya çıkarmaktadır. Çalışanların örgütsel destek algılaması hizmet kalitesi, performans, çalışan tatmini, örgütsel vatandaşlık davranışı gibi pek çok unsur üzerinde etkide bulunmaktadır. Bu çalışma, çalışanların örgütsel destek algılarının boyutlarına dikkat çekmek ve müşterilerin bu algıyı etkileyen bir boyut olduğunu ortaya koymaktadır. Özellikle otel işletmeleri gibi hizmet sektöründe yer alan işletmelerde çalışan tatminini artırmak, örgüte bağlı, örgütün değerlerini benimsemiş ve müşterilere bu değerleri yansıtabilen çalışanların oluşmasında etkili olan örgütsel destek algısının olumlu yönde olması için örgüt yönetimlerine büyük görev düşmektedir. Çalışana örgüt tarafindan sağlanan değil, çalışan tarafindan çevreden kendisine doğru akan bilgileri alma, düzenleme ve yorumlama süreci (Erdoğan, 1996: 2) olarak ifade edilen bu algı çalışanın işe ve örgüte karşı tutum ve davranışlarını da etkilemektedir. Otel işletmeleri kapsamında algılanan örgütsel desteğin boyutlandırılmasına ilişkin önerilen bu modelin diğer hizmet işletmelerinde de (benzer özelliklerin var olduğundan hareket ederek) geçerli olacağı düşünülmektedir.

Çalışma kavramsal bir model önerisi olmakla birlikte, otel işletmelerinde örgütsel destek algılaması konulu ileride yapılacak uygulamalı çalışmalara yol gösterici olacağı ifade edilebilir. Çalışmada sunulan modelin oluşturulmasında, Ma ve Qu tarafindan otel işletmelerinde sosyal değişimin yönetici, çalışma arkadaşı ve müşteri etkileşimi şeklinde üç grubu olduğunu ileri süren yaklaşımından yararlanılmıştır. Araştrmacılar, sosyal değişim teorisini otel işletmelerinde örgütsel vatandaşlık davranışı yaklaşımına uygulayarak, müşteri boyutu ile ilgili sundukları modele ilişkin yaptkkları araştırmadan modeli destekleyen sonuçlar elde etmişlerdir. Bu çalışmada da, benzer bir yaklaşımdan hareket edilerek çalışanların örgütsel destek algısına müşteri boyutunun da eklenmesine ilişkin bir model sunulmuştur. Otel işletmelerinde konu ile ilgili gelecekte yapılacak araştrrmalarda yönetici etkileşimi, çalışma arkadaşları etkileşiminin yanı sıra müşteri etkileşimi boyutunun da eklenerek algılanan örgütsel desteğin açıklanmasında kullanılıp kullanılamayacağı incelenebilir.

Çalışmanın sınırlılıklarını incelediğimizde, bir model önerisi olması en önemli sınırlılığını oluşturmaktadır. Bunun aşılabilmesi ve çalışmanın alana katkı sağlayabilmesi için öncelikle modelin ilk olarak önerildiği otel işletmeleri kapsamında sınanması gerekmektedir. Ardından, turizm işletmelerinin diğer alt dallarında (seyahat işletmeleri, yiyecek-içecek işletmeleri gibi) araştırmaların yapılması sonuçların genellenebilmesine katkı sağlayacaktır. Ardından, hizmet işletmeleri kapsamında yapılacak örgütsel destek araştırmalarında da model kullanılabilir. Ancak, çalışmanın alana katkı sağlayabilmesinde en önemli noktalardan biri otel işletmeleri kapsamında yürütülecek bir araştırmada modele uygun bir ölçeğin kullanılmasına bağlıdır. Aksi taktirde, farklı işletmelerde geçerlilik ve güvenilirliği saptanmış bir ölçekle aynı modelin sınanması hatalı sonuçlara yol açabilir. Illeride yapılacak çalışmalarda bu durumun da mutlaka dikkate alınması gerekmektedir. 


\section{KAYNAKÇA}

Abeysekera, I. (2006). Managing Human Capital in a Privately Owned Public Hotel Chain. International Journal of Hospitality Management, 25, 586-601.

Arshadi, N. (2011). The Relationships of Perceived Organizational Support (POS) with Organizational Commitment, In-Role Performance, and Turnover Intention: Mediating role of Felt Obligation. Procedia-Social and Behavioral Sciences, 30, 1103- 1108.

Arshadi, N. ve Hayavi, G. (2013). The Effect of Perceived Organizational Support on Affective Commitment, and Job Performance: Mediating Role of OBSE. Procedia-Social and Behavioral Sciences, 84, 739-743.

Aselage, J. ve Eisenberger, R. (2003). Perceived Organizational Support and Psychological Contracts: A Theoretical Integration. Journal of Organizational Behavior, 24, 491-509.

Bell, S. J. ve Menguc, B.(2002). The Employee-Organization Relationship, Organizational Citizenship Behaviors, and Superior Service Quality. Journal of Retailing, 78(2): 131-146.

Bettencourt, L. A., Gwinner, K. P. ve Meuter, M. L. (2001). A Comparison of Attitude, Personality, and Knowledge Predictors of Service-Oriented Organizational Citizenship Behaviors. Journal of Applied Psychology, 86 (1), 29-41.

Bishop, J. W., D. K. Scott ve S. M. Burroughs (2000). Support, Commitment, and Employee Outcomes in A Team Environment. Journal of Management, 26 (6), 1113-1132.

Blau, P.M. (1964). Exchange and Power In Social Life. New York: Willey.

Bontis, N. (1998). Intelectual Capital: An Explotary Study that Develops Measures and Models. Management Decision, 36/2, 63-76.

Bontis, N., Keow, W.C.C. ve Richardson, S. (2000). Intellectual Capital and Business Performance in Malaysian Industries. Journal of Intellectual Capital, 1 (I), 85-100.

Booms, B.H. ve Bitner, M. J. (1981). Marketing Strategies and Organization Structure for Service Firms. J. Donnelly ve W. George (Eds.), Marketing of Services içinde (s. 47-51). Chicago: American Marketing.

Borman, W.C. ve Motowidlo, S. J. (1993). Expanding the Criterion Domain to Include Elements to Contextual Performance. N. Schmitt ve W.C. Borman (Eds.), Personnel Selection in Organizations içinde(s. 71-98). San Fransisco: Jossy-Bass.

Börü, D. ve Güneşer, B. (2006). Algılanan Örgütsel Destek ve Lider Üye Etkileşiminin Örgütsel Vatandaşlık Davranışı İle illişkisi ve Güvenin Rolü. Öneri Dergisi, 7 (25), 43-58.

Brooking, A. (1996). Intellectual Capital; Core Assets for the Third Millennium Enterprise. London: International Thomson Business Press.

Buckley, P.J. ve Carter, M.J. (2000). Knowledge Management in Global Technology Markets Applying Theory to Practice. Long Range Planning, 33 (1), 55-71.

Carmen, J.M. ve Langeard, E. (1980). Growth Strategies of Service Firms. Strategic Management Journal, 1, 7-22.

Castro, G.M., Saez, P. L. ve Lopez, J. E. N. (2004). The Role of Corporate Reputation in Developing Relational Capital. Journal of Intellectual Capital, 5 (4), 575-585.

Chang, A. ve Tseng, C. (2005). Building Customer Capital Through Relaionship Marketing Activities. Journal of Intellectual Capital, 6 (2), 253-266.

Chen, Z. X., Aryee, S. ve Lee, C. (2005). Test of Mediation Model of Perceived Organizational Support. Journal of Vocational Behavior, 66, 457-470.

Chow, I. H.-S, Lo; T. W.-C., Sha, Z. ve Hong, J. (2006). The Impact of Developmental Experience, Empowerment, and Organizational Support on Catering Service Staff Performance. International Journal of Hospitality Management, 25, 478-495.

Demircan Çakar, N. ve Yıldız, S. (2009). Örgütsel Adaletin İş Tatmini Üzerindeki Etkisi: “Algılanan Örgütsel Destek" Bir Ara Değişken Mi?. Elektronik Sosyal Bilimler Dergisi, 8 (28), 68-90.

Dimitriades, Z. S. ve Maroudas, T. (2007). Internal Service Climate and Psychological Empowerment among Public Employees an Exploratory Study in Greece, Transforming Government: People. Process and Policy, 1 (4), 377-400.

Edmondson, D. R. ve Boyer, S. L. (2013). The Moderating Effect of the Boundary Spanning role on Perceiev Supervisory Support: A Meta-Analytic Review. Journal of Business Research, 66, 2186-2192.

Edvinsson, L. ve Malone, M. S. (1997). Intellectual Capital. New York, NY: Harper Business.

Eisenberger, R., Huntigton, R., Hutchison, S. ve Sowa, D. (1986). Perceived Organizational Support. Journal Of Applied Psychology, 71(3), 500-507.

Eisenberger, R., Cummings, J., Armeli, S. ve Lynch, P. (1997). Perceived Organizational Support, Discretionary Treatment, and Job Satisfaction. Journal of Applied Psychology, 82(5), 812-820. 
Emrem, A. Erdinç. (2004). Entelektüel Sermaye ve Bileşenlerinin Kavramsal Analizi. e-dergi Iş-Güç Endüstri illişkileri ve Insan Kaynakları Dergisi, 6 (1).

Ercan, M. K., Demirgüneş, K. ve Öztürk, M. B. (2003). Değere Dayalı Yönetim ve Entelektüel Sermaye. Ankara: Gazi Kitabevi.

Erdoğan, İ. (1996). İşletme Yönetiminde Örgütsel Davranış. İstanbul: İşletme Fakültesi Yayını.

Ferris, D. L., Brown, D. J. ve Heller, D. (2009). Organizational Supports and Organizational Deviance: The Mediating Role of Organization-Based Self-Esteem. Organizational Behavior and Human Decision Processes, 108, 279-286.

Fuller, J. B., Hester, K. ve Barnett, T. (2006). Perceived Organizational Support and Perceived External Prestige: Predicting Organizational Attachment for University Faculty, Staff, and Administrators. The Journal of Social Psychlogy, 146 (3), 327-347.

Fuller, J. B., Barnett, T., Hester, K. ve Relyea, C. (2003). A Social Identity Perspective on the Relationship between Perceived Organizational Support and Organizational Commitment. The Journal of Social Psychology, 143(6), 789-791.

Gakovic, A. ve Tetrick, L. E. (2003). Perceived Organizational Support and Work Status: a Comparison of the Employment Relationships of Part-Time and Full-Time Employees Attending University Classes. Journal of Organizational Behavior, 24, 649-666.

Giray, M. D. (2013). İş Yeri Desteği: Örgüt, Yönetici Ve Çalışma Arkadaşları Desteğine Genel Bir Bakış. "iş, GüÇ" Endüstri Iliş̧kileri ve Insan Kaynakları Dergisi, 15 (3), 67-81.

Guthrie, J. (2001), The Management Measurement and the Reporting of Intellectual Capital. Journal of Intellectual Capital, 2 (1), 27-41.

Güçlü Nergiz, H. (2016). Turizm Sektöründe Örgütsel Vatandaşlık Davranışı Üzerine Bir Değerlendirme. Yönetim Bilimleri Dergisi, 14 (27), 217-247.

Güzel, B. ve Iş̧̧i, C. (2015). Örgütsel Destek Algısı. D. Küçükaltan, Ş. Aydın Tükeltürk ve G. Ç. Gürkan (Ed), Örgütsel Davranışta Güncel Konular içinde (s. 125-143). Ankara: Detay Yayıncılık.

Hartline, M. D. ve Ferrell, O. C. (1996). The Management of Customer-Contact Service Employees: an Empirical Investigation. Journal of Marketing, 60 (4), 52-70.

Hennig-Thurau, T. (2004). Customer Orientation of Service Employees: Its Impact on Customer Satisfaction, Commitment, and Retention. International Journal of Service Industry Management, 15(5), 460-478.

Hogan, J., Hogan, R. ve Busch, C.M. (1984). How to Measure Service Orientation?. Journal of Applied Psychology, 69 (1), 167-173.

İplik, E., İplik, F. N. ve Efeoğlu, İ. E.(2014). Çalışanların Örgütsel Destek Algılarının Örgütsel Vatandaşlık Davranışı Üzerindeki Etkisinde Örgütsel Özdeşleşmenin Rolü. International Journal of Economic and Administrative Studies, 6 (12), 109-122.

Kalağan, G. (2009). Araştırma Görevlilerinin Örgütsel Destek Algıları ile Örgütsel Sinizm Tutumları Arasındaki illişki (Yayınlanmamış Yüksek Lisans Tezi). Akdeniz Üniversitesi/ Sosyal Bilimler Enstitüsü, Antalya.

Kaplan, R. S. ve Norton, D. P. (1992). The Balanced Scorecard Measure that Drive Performance. Harvard Business Review, 70 (1), 71-79.

Kurgun, O. A. ve Akdağ, G. (2013). Entelektüel Sermaye ve Örgüt Performansı Illişkisi: Akdeniz Bölgesindeki Otel İşletmelerinde Bir Araştırma. NEÜ Sosyal Bilimler Enstitüsü Dergisi, 2, 155-176.

Lee, G., Magnini, V. P. ve Kim, P. (2011). Employee Satisfaction with Schedule Flexibility: Psychological Antecedents and Consequences within the Workplace. International Journal of Hospitality Management, 30: 22-30.

Lovelock, C. H. (1981). Why Marketing Management Need to The Different for Services. J. Donelly, J. ve W. George (Eds.), Marketing of Sciences içinde (s. 5-9). Chicago: American Marketing.

Lyu, Y., Zhu, H., Zhong, H. J. ve Hu, L. (2016). Abusive Supervision and Customer-Oriented Organizational Citizenship Behavior: The Roles of Hostile Attribution Bias and Work Engagement. International Journal of Hospitality Management, 53, 69-80.

Ma, E. ve Qu, H. (2011). Social Exchanges as Motivators of Hotel Employees' Organizational Citizenship Behavior: The Proposition and Application of a New Three-Dimensional Framework. International Journal Of Hospitality Management, 30, 680-688.

Masterson, S. S. (2001). A Trickle-Down Model of Organizational Justice: Relating Employees' and Customers' Perceptions of and Reactions to Fairness. Journal of Applied Psychology, 86, 594604.

Organ, D.W., Podsakoff, P.M. ve Mackenzie, S.B. (2006). Organizational Citizenship Behavior. Its Nature, Antecedents, and Consequences. CA: Sage, Thousand Oaks. 
Orpen, C. (1994). The Effects of Exchange Ideology on the Relationship between Perceived Organizational Support and Job Performance. Journal of Social Psychology, 134 (3), 407-408.

Ölçer, F. ve Şanal, M. (2007). İşletmelerde Entelektüel Sermaye Yönetimi. Ç.Ü. Sosyal Bilimler Enstitüsü Dergisi, 16 (1), 479-500.

Özdaşlı, K., Kanten, P. ve Alparslan, M. (2013). Lider-Üye Etkileşiminin Proaktif Davranışlar Üzerindeki Etkisi. 21. Yönetim ve Organizasyon Kongresi Bildiriler Kitabı, 208- 214.

Özdemir, L. ve Balkan, O. (2010). Entelektüel Sermaye Unsurlarının İşletmelere Sağladığı Katkılar. Organizasyon ve Yönetim Bilimleri Dergisi, 2 (1), 115-121.

Özdevecioğlu, M. (2003). Algılanan Örgütsel Destek İle Örgütsel Bağılık Arasındaki İlişkilerin Belirlenmesine Yönelik Bir Araştırma. Dokuz Eylül Üniversitesi i.i.B.F. Dergisi, 18(2),113-130.

Pablos, P. O. (2002). Evidence of Intellectual Capital Measurement From Asia Europe an the Middle East. Journal of Intellectual Capital, 3 (3), 287-302.

Paksoy, H. M. ve Öztürk, M. C. (2006). Otel İşletmelerinde Entelektüel Sermayenin Oluşumu: GAP Örneği. Yönetim Bilimleri Dergisi, 4(2), 133-159.

Podsakoff, P. M. ve Mackenzie, S.B. (1997). Impact of Organizational Citizenship Behavior on Organizational Performance: A Review and Suggestions for Future Research. Human Performance, 10, 133151.

Riley, M. (1996). Human Resource Management in the Hospitality and Tourism Industry (2 nd ed). Oxford: Butterworth-Heinemann.

Rhoades, L. ve Eisenberger, R. (2002). Perceived Organizational Support: A Review of The Literature. Journal of Applied Psychology, 87 (4), 698-714.

Rudez, H. N. ve Mihalic, T. (2007). Intellectual Capital in the Hotel Industry: A Case Study from Slovenia. International Journal of Hospitality Management, 26, 188-199.

Shore, L. M. ve Wayne, S. J. (1993). Commitment and Employee Behavior: Comparison of Affective Commitment and Continuance Commitment with Perceived Organizational Support. Journal of Applied Psychology, 78 (5), 774-780.

Shore, L. M. ve Shore, T. H. (1995). Perceived Organizational Support and Organizational Justice. R. S. Cropanzano, K. M. Kacmar (Eds.), Organizational Politics, Justice, and Support: Managing The Social Climate of The Workplace içinde (s. 149-164). Westport, CT: Quorum.

Sierra, F. F. ve Mcquity S. (2005). Service Providers and Customers: Social Exchange Theory and Service Loyalty. Journal of Services Marketing,19 (6), 392-400.

Sluss, D. M., Klimchak, M. ve Holmes, J. J. (2008). Perceived Organizational Support as A Mediator Between Relational Exchange and Organizational Identification. Journal of Organizational Behavior, 73: 457-464.

Stamper, C. L. ve Johlke, M. C. (2003). The Impact of Perceived Organizational Support On The Relationship Between Boundary Spanner Role Stress and Work Outcomes. Journal of Management, 29(4), 569-588.

Sveiby, K. E. (1997). The New Organizational Wealth: Managing and Measuring Knowledge- Based Assets, New York, NY: Berrett- Koehler.

Thorne, K. ve Smith, M. (2000). Competitive Advantage in World Class Organisations. Management Accounting, 78 (3), 22-26.

Tsan, W. N. ve Chang, C. C. (2005). Intellectual Capital System Interaction in Taiwan. Journal of Intellectual Capital, 6 (2), 285-298.

Volberda, H. W., Baden-Fuller, C. ve van den Bosch, F. A. J. (2001). Mastering Strategic Renewal, Mobilising Renewal Journeys in Multi-Unit Firms. Long Range Planning, 34, 159-178.

Yoon, J. ve Thye, S. R. (2002). A Dual Process Model of Organizational Commitment. Work and Occupations, 29 (1), 97-124.

Wayne, S. J., Shore, L. M.ve Liden, R.C. (1997). Perceived Organizational Support and Leader-Member Exchange: A Social Exchange Perspective. Academy of Management Journal, 40(1), 82-111.

Wood, R. C. (1997). Working in Hotels and Catering. London: International Thomson Business Press.

Wu, T.Y., Lee, S. J, Hu, C. ve Yang, C. C. (2014). When Supervisors Perceive Non-Work Support: Test of a Trickle-Down Model. The Journal of Psychology: Interdisciplinary and Applied, 148(2), 215-251.

Zagenczyk, T. J., Scott, K. D., Gibney, R., Murrell, A. J. ve Thatcher, J. B. (2010). Social Influence and Perceived Organizational Support: A Social Networks Analysis. Organizational Behavior and Human Decision Processes, 111, 127-138.

Zeithaml, V. (1987). Defining and Relating Price, Perceived Quality, and Perceived Value (Report No. 87101). Cambridge, MA: Marketing Science Institute. 